\title{
Simultaneously deepening corporatism and advancing neoliberalism: Australia under the Accord
}

Elizabeth Humphrys, University of Technology Sydney

\begin{abstract}
Given recent calls for a new social contract between the unions and government, it is timely to consider the relationship of the ALP and ACTU prices and incomes Accord (1983-1997) to the construction of neoliberalism in Australia. Contrary to most scholarly accounts, which posit the ALP and ACTU prices and incomes Accord (1983-1997) and neoliberalism as exogenously-related or competing processes, this article argues they were internally-related aspects of economic transformation. The implementation of the Accord agreement deepened Australia's existing corporatist arrangements while simultaneously advancing neoliberalism within a highly structured political-economic framework.
\end{abstract}

\section{Keywords}

Neoliberalism, Accord, Australia, corporatism, Gramsci

\section{Autobiographical note}

Elizabeth Humphrys, PhD, is a lecturer at the University of Technology Sydney. Her recent doctoral thesis analysed the implementation of neoliberalism in Australia, and its relationship to the ALP and ACTU Accord. Her latest research is on the phenomenon of anti-politics.

\section{Introduction}

In his ground-breaking work Economic Rationalism in Canberra (1991), Michael Pusey investigated the 
recasting of the Australian political economy along neoliberal (or economic rationalist ${ }^{1}$ ) lines in the 1980s. His focus was on the transformation and actions of Australia's top bureaucrats. This article examines another aspect of that transformation, by investigating the relationship between the Accord social contract and neoliberalism, focussed on the trade unions were incorporated into a hegemonic neoliberal project. Given recent calls for a new Accord-style agreement between the unions and a future Labor government to manage the economy (Emerson 2015; Howes 2014), it is timely to consider the social contract's role in the construction of neoliberalism in Australia.

The article initially outlines the general scope of the Accord and vanguard neoliberalism in Australia and sets out a framework for understanding corporatist arrangements. It then details the dominant approach to conceptualising the relationship between corporatism and neoliberalism, a method that views corporatism and neoliberalism as alternate, mutually exogenous or opposed policy frameworks and political projects. It also critically examines the informal Accord conception, which has been offered as an alternative understanding of the relationship by several Marxist scholars. The article argues that neither approach adequately theorises the relationship between the Accord and neoliberalism. A new approach is offered through examining the corporatist Accord and neoliberalism as two intertwined and mutually reinforcing sides of a unitary project of economic transformation. This is achieved by an empirical focus on three key aspects of this social contract: the integration of militant unions into the Accord through a focus on the Amalgamated Metal Worker's Union (AMWU); the containment of wage increases; and the suppression of industrial struggle. It is argued that these central tenets of the Accord directly facilitated the neoliberal objective of labour (trade union) disorganisation. The article concludes that an approach that views the Accord and neoliberal policy making as internally related offers a richer understanding of economic transformation in Australia in that period. It describes the relationship between the Accord and vanguard neoliberalism in Australia as a process of simultaneously deepening corporatism and advancing neoliberalism, and conceptualises this using Antonio Gramsci's notion of the integral state.

One of the limitations of the international literature on both corporatism and neoliberalism has been its limited exploration and analysis of locations where the roll-out of vanguard neoliberalism was concurrent with the use of corporatist arrangements (Krinsky 2011). Although some authors have

\footnotetext{
${ }^{1}$ Initially neoliberalism was called 'economic rationalism' in Australia, terms treated as synonymous by many authors (Frankel 1997) and in this article.
} 
noted how neoliberalism emerged from 'among its others', such work has been of a general and suggestive character (Peck et al. 2009; Jessop 2002). This article investigates the Australian Accord as a distinct spatial example of neoliberalism emerging alongside-and through-corporatism. The article contributes to both a deeper understanding of the relationship between the Accord and neoliberalism, as well as to an emerging international literature concerned with the relationship between corporatism and neoliberalism.

\section{The Accord}

Signed by the Australian Labor Party (ALP) and the Australian Council of Trade Unions (ACTU), and in place between 1983 and 1996, the Accord functioned as the primary statement of domestic economic policy under the Hawke-Keating ALP Governments (Ahlquist 2011: 133). The agreement was reconstituted through national wage cases and renegotiated terms over 13 years and eight 'editions' (Mark I-VIII). The original statement set out wide-ranging economic and social policy. In return for trade unions restraining wage demands to the level of inflation and making 'no further claims' via industrial action, the agreement promised moderation on prices and non-wage incomes, an expansion of the social wage, and the implementation of progressive tax reform. The Accord reintroduced centralised wage fixation and sought to promote growth through economic management and central planning. However, as is generally acknowledged, the process quickly narrowed to focus primarily on wages.

The Accord was introduced at the same time as vanguard neoliberalism in Australia. The vanguard neoliberal period was characterised by the initial and most intense period of implementation of neoliberal policies. This article understands neoliberalism as a state-centred hegemonic political project for the remaking of capitalist production and social reproduction, which has gained ascendancy since the end of the long boom. Neoliberalism is understood as a political project that cannot be defined only by a simple and consistent set of ideas, policies and/or economic outcomes across different spatial and temporal instances (Cahill 2013). Nevertheless, in capitalist terms, it does constitute a relatively coherent and logical response to the specific features of the protracted global economic crisis of the 1970s and 1980s.

Neoliberalism is shaped by a macroeconomic approach that sees inflation as a greater risk to economic development than unemployment and promotes the benefits of markets over state action (Bieler 2007: 112). In general terms, 'neoliberalism can be broadly defined as the extension and 
installation of competitive markets into all areas of the economy, politics and society' (Birch 2015: 571). In Australia in the Accord era, the state implemented an 'inflation first' strategy and a suite of economic and social reforms similar to those usually viewed as part of the advance of neoliberalism globally. These included: floating the Australian dollar and abolishing exchange controls; deregulating the financial and banking sectors; dismantling the tariff system and promoting 'free trade'; widespread industry deregulation; privatisation of government-owned entities; corporatisation of government departments and contracting out of services; marketisation of the retirement payments system; the adoption of competition policy frameworks; imposition of a level of austerity on the working class; and, over time, the introduction of a 'deregulated' labour market in the form of enterprise bargaining.

\section{Corporatism and neoliberalism}

Corporatism has generally been understood as distinct from pluralism, which is centred on group multiplicity and a passive or dispassionate state (Panitch 1981: 25). However, understandings of corporatism are contested. It has been variously understood as interest representation; institutionalised patterns of policy formation; interventionist state economic policy directed predominantly at business; a structure for managing conflict in advanced capitalism; and a tool of social control (Wilson 1983: 106-107). Gerhard Lehmbruch's (1977) influential work argued corporatism is a mode of policy-making, while Philippe C Schmitter's (1979: 9) important approach defined it as a 'system of interest and/or attitude representation' where institutional arrangements link the 'associationally organised interest of civil society with the decisional structures of the state'. For most scholars, corporatism is understood at a basic level to refer to 'a political power structure and practice of consensus formation based on the functional representation of professional groups' (Czada 2011).

However, these influential approaches did not adequately interrogate the location of corporatism in the wider capitalist system. Schmitter's analysis, and that of many leading proponents, provided 'little theoretical invitation to challenge pluralism's assumption of state neutrality between the groups or to address the differential power position of the groups themselves in the society' (Panitch 1980: 167). Indeed, it remained 'a "group-theoretical" rather than a "class-theoretical" approach' (Panitch 1980: 169). This article uses utilises Panitch's $(1976 ; 1986)$ Marxist account of the use of corporatist frameworks by liberal democratic governments, and in particular considers their deployment in periods of economic crisis. Panitch (Panitch 1981: 24) argued that the corporatist paradigm 
'integrates organised socioeconomic producer groups through a system of representation and cooperative mutual interaction at the leadership level and of mobilisation and social control at the mass level'. In this way, corporatism is 'an actual political structure, not merely an ideology' (Panitch 1981: 24). Panitch's approach is considered most suitable for analysing the Accord, as it does not view politics and economics as having an external relationship. In utilising Panitch's approach, this paper understands that corporatism and neoliberal restructuring do not involve an external relationship, where they are opposed policy processes, but an internal one as part of an overall political economic program.

This article focuses on how several structural mechanisms of the Accord facilitated and embedded certain neoliberal objectives, most particularly the suppression of real wages, the disorganisation of labour, and the modification of labour market regulations. Thus, Panitch's account—which emphasises corporatism's class nature, its role in social control, and the subjective agency of political society in bringing about such arrangements-is especially helpful. Corporatism and, in particular, the incomes policy component:

... involves the explicit acceptance by the organised working class of the claim that there is a community of interests within existing society, [and] that the harmony between classes posited by a national integrative political party does in fact exist (Panitch 1976: 3).

As a result:

... when social democracy translates working class loyalty to its party into loyalty to the nation, the basic dilemma of corporatism—coercion in the name of harmony—comes to rear its ugly head (Panitch 1976: 247).

Panitch's account helps to fill in the concrete details of how such a process can occur through the establishment of corporatist political structures.

While Panitch was clear that corporatism is a state-centred and state-managed class project of integration, Gramsci's conception of the integral state can also assist us in better understanding the relationship between the Accord and the vanguard phase of neoliberalism. Gramsci developed the conception of the integral state as part of a critique of the liberal conception of the 'separation of powers' (Morton 2007). Rather than seeing the state as genuinely universalising in its project, Gramsci argued that the integral state is a process of capitalist class domination and hegemony. The integral state is an understanding of how the state (political society and the state apparatus) comes to lead or direct civil society (atomised social interests and the relations between them) politically_and 
how, in particular, it responds to social and political dissent to projects focused on ensuring stable capital accumulation. The integral state is 'a network of social relations for the production of consent, for the integration of the subaltern classes into the expansive project of historical development of the leading social group' (Thomas 2009: 143).

Gramsci's concept of the integral state described a specific relationship between the state and civil society, where processes of consent ('hegemony') in civil society are just as important as openly coercive state rule ('domination'). Gramsci conceived the integral state not as an 'identity' between the state and civil society (i.e. the same as each other), nor as a 'fusion' (i.e. distinct but in union)but rather as a dialectical unity (Thomas 2009: 69). He deployed a specific understanding of this dialectical unity as a process of envelopment or enwrapping ('involucro) of civil society by political society (Thomas 2009: 189). For Gramsci, conceiving of the state as something that simply sits above civil society, involved in regulation and coercion alone-even through democratic meansoverlooks that it is in practice a 'complex of practical and theoretical activities with which the ruling class not only justifies and maintains its dominance, but manages to win the active consent of those over whom it rules' (Gramsci 1971: 244; Q15 \$10). In relation to the Accord, Gramsci's conception of the integral state helps us explore how the enwrapment of the labour movement through a social contract, allowed the construction of a new hegemonic project in the form of neoliberalism.

\section{Alternate or opposed frameworks?}

The concordance between the Accord and neoliberalism is not accepted in most of the scholarly literature. The two phenomena are usually seen as opposed economic programs, where the social contract provided a brace against (or moderation of) the advance of neoliberalism, at a time of protracted economic stagnation in which resistance to restructuring was not possible or could not realistically succeed (Spies-Butcher 2012). The Accord has also been seen as a framework that limited the regressive impact of neoliberalism compared with other nations implementing it at the same time-in particular New Zealand, the United States and the United Kingdom (Ahlquist 2011).

David Peetz (2013) posited neoliberalism as something external or additional to the corporatist process and, in a general sense, standing opposed to it. Peetz argued that corporatism was an alternative policy regime (and challenge) to Thatcherism in Great Britain, Reaganomics in the United States and Rogernomics in New Zealand, in that it: 
... brought about a period in which the government worked under contesting ideas. There was no uniformity of thought. When these two big ideas were in contest-market liberalism and the modified Keynesianism of the Accord—sometimes one idea won out, sometimes the other idea did (Peetz 2013).

In his analysis critical of the outcomes of the Accord, Hampson (1997: 540) posits neoliberalism as something external or additional to the corporatist process and, in a general sense, standing opposed to it - engendering 'tensions' between corporatism and neoliberalism, and 'undermining the democratic element in Australian corporatism'. In this approach, corporatism and neoliberalism are seen as conflicting policy stances, with the latter ultimately undermining the former. Spies-Butcher (2012) has argued that the Accord was a process whereby different views on economic management were reconciled, in that it allowed for the interests of all parties to be protected through the collective management of the macro economy. Thus collaboration combined with a realistic approach to macroeconomic management allowed the ALP to achieve 'a pragmatic accommodation between markets and equity' (Spies-Butcher 2012: 208).

Alternatively, a number of Marxist scholars have argued that understanding the Accord and neoliberalism as competing or largely exogenous projects is inadequate, if we are to fully comprehend how the state led a radical transformation of the national political economy. They have sought to overcome this perceived conceptual problem through the notion of an 'informal' Accord. This concept posits that there was a more specific dynamic involved in the relationship, where the trade union leadership tied the labour movement into the priorities of the government through an informal agreement. Tom Bramble and Rick Kuhn (1999), followed later by Damien Cahill (2008), developed and elaborated this notion by arguing that the formal Accord (the provisions set out in the social contract) was supplemented by an ongoing informal commitment by the unions that the ALP should govern regardless of whether the formal agreement was implemented as initially intended. The informal Accord was thus an effort 'to manage the neo-liberal transformation of state and economy by tying the leadership of the labour movement to this process' (Cahill 2008: 326). The strength of such a framework lies in its rejection of portrayals of the social contract and neoliberal transformation as counterposed. Rather, the informal Accord is seen as allowing the introduction of neoliberalism through unions that were willing to compromise significantly their own political and economic objectives to ensure 'their' government remained in power. In the words of Accord architect, Bill Kelty, the: 
... Accord was at one end of the spectrum simply an expression of support for the Labor Party to govern. At the other end of the spectrum it was a working partnership (cited in Cahill 2008: 326).

The informal Accord framework helps to clarify why the ACTU (and even the more radical unions) continued to support the ALP over the thirteen years of the Hawke-Keating Government, despite their concerns about the direction of government policy in the neoliberal era. The framework also logically implies that the arrangement helped facilitate the introduction of neoliberalism, by dulling dissent and providing support for a continued ALP incumbency.

However, framing the connection between the Accord and neoliberal economic transformation in terms of an informal arrangement implies there was something outside the social contract—a hidden agreement between the parties — that was essential to the relationship between corporatism and vanguard neoliberalism. Yet the central motivation and key achievement of the Accord was its agenda of wage restraint and suppression of militancy. These primary objectives of the social contract, of increasing the rate of exploitation and quashing industrial struggle to resolve problems of capital accumulation, also sit at the heart of the vanguard neoliberal project. It is not that neoliberalism was possible simply because the informal agreement allowed the ALP to do it, but because cutting real wages and suppressing militancy were core objectives of both the corporatist and neoliberalism-projects that were internally related. The notion of an informal Accord can, therefore, risk diverting analytical attention from the very direct way in which central tenets of neoliberalism were implemented through the Accord.

The formal aspects of the Accord provided a set of political structures that tied labour to the state, allowing informal understandings about the survival of the ALP government to have the importance they did. This integration of labour was mediated by the participation of trade union officials and activists operating in a set of highly organised, institutionalised, state-centric political relationships with representatives of political society, the state bureaucracy and business elites. The unions had supported 'their' ALP governments before and after the Accord, but in no other situation were the stakes involved in maintaining or withdrawing support so high. This was because in no other situation did the unions find themselves tied so directly to the inner workings of the government and its political-economic reform program. The ability of the ALP to introduce neoliberal reform was a direct result of the formal components of the agreement, especially the inclusion of the unions within state processes and structures.

\section{Simultaneously deepening corporatism and advancing neoliberalism}


While there was a strong temporal overlap between neoliberal reorganisation in Australia and the Accord, this article contends that there was a deeper correspondence between these projects. As detailed above, most scholarly accounts of the Accord argue that the social contract and neoliberalism were counterposed sets of ideas, policies and processes. By way of contrast, this article argues that the Accord and neoliberalism were internally related elements of a state-centred project to restore accumulation after the 1970s economic crisis. To make this case, the article provides an empirically based account of the relationship between the Accord and neoliberalism, focused on the integration of the AMWU2 into the Accord process, the cutting of real wages and its consequences, and the rollback of industrial militancy. The relationship between the Accord and neoliberalism is described as simultaneously deepening corporatism and advancing neoliberalism. When corporatism is understood as a class project of incorporation and subordination of the labour movement into the imperatives of the state, via the structures and ties of the trade unions, then the apparent tension between a social contract and the neoliberal project dissolves in terms of its potential and actual outcomes. The wage and industrial action components of the social contract disorganised a oncepowerful trade union movement, through the integration of the leadership of the ACTU and key unions, and directly facilitated the neoliberal objective of labour disorganisation.

Integrating the AMWU

While worker agency had been central to the labour movement's gains in the long boom and, partially, in the decade after the boom ended, the shift to state agency through the Accord from 1983 delivered a sharp curtailment of labour's power. The social contract incorporated the unions, and in particular the militant AMWU, into the new political project centred on reviving accumulation and 'modernising' the Australian economy. Central to neoliberal restructuring was the participation of unions in industry structural adjustment and efforts to increase productivity. The shift from a workplace-focused strategy to a corporatist one facilitated the enwrapment of labour and the trade union leadership by political society and its priorities.

For the Accord to be accepted, the left and Communist Party of Australia (CPA) aligned unions had to be brought inside the social contract. For the Accord to be maintained, it had to facilitate the suppression of union industrial militancy that so typified the 1970s and early 1980s. Bringing militant

\footnotetext{
${ }^{2}$ For ease, the acronym AMWU is used in this article to refer to the metals/manufacturing workers' union, given it changed its name several time during the Accord years.
} 
unions inside the Accord required a significant shift in the manner in which these unions approached labour organising; but once inside the Accord, a further shift took place as the union leadership was enwrapped (involucro) by political society.

The AMWU was the largest and most powerful trade union in Australia in this period, with the gains it made through shop floor industrial action often flowing onto other segments of the working class. Without the sanction and ongoing support of the AMWU over the Accord era, the social contract could not have been cohered (Singleton 1990: 61). In the early 1970s, the AMWU achieved increased real wages through industrial action and this contributed to an increased wages share of national income (Bramble 2001: 8). This militant strategy was undermined from the mid-1970s onwards by recessions - but most particularly by the recessions of the early 1980s-which, up to that time, led to 'the worst labour market conditions since the Depression' (Beggs 2015: 260). The AMWU had scuttled social contract efforts in the 1970s (Singleton 1990) and, as such, the terms of the Accord were explicitly developed to win over the AMWU and other CPA unions to a social contract. The union leadership came to believe it could not win back the lost jobs without a coordinated plan across industry, and that an expanded social wage-including an increase to the level of unemployment benefits—-was necessary in the context of escalating job losses.

In order to enter the Accord, the AMWU shifted from being a union with intellectual resources focused on operating relatively independently of political society and the state, and strategically using those resources to encourage greater activity of the rank and file and shop committees. It was reconstituted as an organisation that devoted its capacities to an alliance with a Labor Government — a decision that abnegated those democratic and mobilisational features (Scalmer and Irving 1999). Bramble (2000: 179) described this change quite directly, stating the AMWU moved from 'being a byword for industrial activism in the late 1960s and early 1970s' to, by the end of the Hawke-Keating era, being 'a mainstream supporter of the ALP establishment [with] its formerly extensive and militant shop steward networks [having] undergone severe corrosion'. The transformation of the AMWU was profound, both structurally and in terms of the political outlook of its leadership. Its decision to shift orientation from one of relative independence from the state to one driven by a commitment to corporatist wage outcomes and industrial action suppression, resulted in it becoming more closely integrated into the state and increasingly dependent on links to state power rather than its membership and ground-level organisation. Thus, the union became a leading civil society actor willingly exchanging its independence from the state for a role in political 
society, along the lines predicted by Panitch's critique of corporatism.

\section{$\underline{\text { Wage suppression }}$}

The Accord's wages and bargaining trajectory is best understood as a key element in labour disorganisation, and one that directly contributed to the neoliberal project for two reasons. First, the shift from workplace-based organising in the pre-Accord period-which had previously provided coherence to the labour movement - to a centrally arbitrated process disorganised the labour movement at the rank-and-file level. Second, real wage suppression necessitated the inhibition of industrial activity. Wages policy under the Accord represented, therefore, a simultaneous deepening of corporatism and advance of neoliberalism—achieved by undermining labour remuneration, conditions and organisation.

The suppression of wages and wage share_-as well as the related disorganisation of labour and subdual of industrial activity—was achieved differently in states with which Australia is often compared (in particular the UK, US and NZ). Unlike the situation in those countries, the processes that led to declining wage share and industrial action in Australia were primarily voluntary. These objectives were organised by the trade union movement, through the reinvigoration of a centralised wages system that significantly reduced the need for rank-and-file involvement in wage bargaining and trade unions more generally. This process allowed wages policy to be directed by the ALP Government and saw the ACTU offer up organised labour — and its ability to accede to increased exploitation — as part of a macroeconomic policy framework entirely consistent with neoliberalism. The Accord agreement detailed that the parties had accepted wage moderation to the level of inflation, and the implementation of the Accord had an immediate impact on nominal award wages and average weekly earnings (which slowed from the 1983-84 financial year). Wages growth between 1985 and 1987 was well below CPI and continued declining until the 1991-1992 financial year. Michael Beggs (2015: 270) has noted that 'it should not be taken for granted that the Accord was entirely responsible for this restraint - it was also, after all, a period of historically high unemployment'. In terms of the identifiable contribution of the Accord to wage suppression, the 'consensus of a number of econometric studies... is that the Accord had substantial effects on the rate of growth of both nominal and real wages' (Beggs 2015: 270). Thus, the Accord helped to reduce the average real level of wages, which did not recover to their pre-Accord levels until the final year of the Accord (Humphrys 2016). 
Beggs (2015: 273) has usefully focused attention on how the Accord was able to transform the arbitration system into an instrument of macroeconomic policy, realising a 'long held dream of Australian macroeconomists'. The agreement achieved the suppression of real wages, which had 'proven impossible to impose from above ... due to the nature of the arbitration system-part of the state, but not under the control of the government or policy makers' (Beggs 2015: 273). Thus, the import of the Accord was that it voluntarily drew the unions into wage suppression, enwrapping them in the state's priorities in the vanguard neoliberal era and enacted that through the arbitration process.

\section{Suppressing industrial action}

The implementation of neoliberalism has typically entailed the defeat of key sections of the labour movement. In the US, this included the 1981 PATCO union dispute when Ronald Reagan fired 11,359 striking air traffic controllers (Harvey, 2005: 25). In the UK, the key defeat was of the 12month long 1984-1985 miners' strike by Thatcher (Rogers 2014: 291). In Australia, the disorganisation of labour involved both voluntary industrial restraint, and the active policing of workers' industrial action by business, the state, and the organised labour movement itself.

There were three ways in which industrial activity was suppressed and the labour movement disorganised: (i) through New Right efforts to curb industrial power by targeting strike action; (ii) in the policing of renegade unions by the union movement and/or the holding back of solidarity for unions taking action; and (iii) through the active suppression of industrial struggle by the ALP government. To demonstrate these methods, the article briefly considers civil legal action against unions, the 1986 deregistration of the Builders Labourers' Federation, and the defeat of the 1989 pilots' strike.

In the early years of the Accord, elements of the New Right mobilised to take civil action against various unions. While companies impacted by industrial action officially took the legal remedies, employer organisations underwrote the legal costs and helped coordinate these efforts. In doing this, business 'organisations such as the National Farmers Federation (NFF) and the Melbourne Chamber of Commerce were not merely protecting the interests of their own members, [but] actively trying to reshape the Australian political landscape' (Cahill 2010: 14). The Accord created openings for these offensives, 'because the officials were determined to avoid a generalised union response [to the New Right attacks] which would in turn undermine the enforced passivity' of the social contract (Griffiths 1989). 
In a key example of the New Right efforts, in 1985 the Amalgamated Meat Industry Employees' Union (AMIEU) commenced industrial action at the Mudginberri Abattoir near Darwin in the Northern Territory (NT). The owners of the abattoir took action under the Trade Practices Act, with the support of the NFF, as part of a strategy of militant managerialism by the New Right (Brian 1999). The union was found guilty of breaching legal injunctions and, after a $\$ 100,000$ fine was imposed, it lifted the picket. By the end of the dispute, the total fines and damages ordered against the union were in the range of $\$ 2.7$ million (Ericsen 2004). The Mudginberri dispute resulted in no call from within the trade unions to mount a generalised campaign to defeat the use of the legislation. During the dispute, the ACTU Congress passed a motion calling for support for the workers and a number of unions made donations to the dispute (Bramble 2008: 141). However, despite these isolated acts of solidarity, the labour movement and trade union leadership 'failed to get squarely behind the AMIEU' - even though the meatworkers were acting in line with ACTU policy in defying the court orders (Ericsen 2004). Other unions that attempted to go outside the Accord in the 1983-196 period, to recover wages lost in the pre-Accord period, were also defeated through the use of civil action and the failure of the ACTU to support the workers involved in the disputes (McPhillips 1985).

In an example of policing renegade unions, in the early 1980s the ALP and ACTU aligned in efforts to deregister one of the most radical and militant unions in the country-the Builders' Labourers Federation (BLF). Allegations of corruption in the BLF were clearly substantive and intractable issues in the deregistration, but they simultaneously provided a way for the ACTU to deal with a potential Accord dissident that had a history of militant struggle (Bramble 2008: 136). The union appeared to have little intention of abiding by the Accord, and in 1983 it campaigned for a wage claim outside its terms (Bramble 2008: 135). Bob Carr, then a journalist and later the ALP Premier of NSW, wrote 'that the action presented the ALP and ACTU "with a challenge they must crush"'-given any victory for the BLF might mean the ACTU found 'it impossible to stop flowons, first to oil workers, then the metalworkers, ensuring it would spread around the country' (cited in Ross 2004). Carr expressed concern that if the BLF was successful, it would undermine 'the ACTU's ability to police the union movement' (Ross 2004). While some unions, including those aligned to the ALP Socialist Left faction in Victoria, opposed the deregistration of the union, there was no significant union movement action to stop the process. The BLF was expelled from the arbitration system, cancelling the relevant awards for its members and leading to the union's eventual demise (Kaptein 1993: 101-2). 
Finally, in an example of direct suppression of industrial struggle against the Accord, the ALP and ACTU actively undermined the 1989-1990 pilots' dispute involving the Australian Federation of Air Pilots (AFAP). After six years of real wage suppression, coupled with increasing and record profits in the airline industry in the latter part of the 1980s, the AFAP lodged a pay claim in May 1989 on behalf of pilots at the government-owned Australian Airlines (Norington 1990: 24). The resulting industrial action had a significant impact on airline travel and tourism. In that context, the ALP took the decision to use defence force personnel and overseas pilots as strikebreakers, to cover limited domestic airline services. The union was roundly defeated, with only a small number of pilots reemployed on individual contracts (as opposed to the old award) by the airline. During the dispute, the ACTU abandoned the union; then ACTU President Simon Crean (later an ALP government minister) stated that having chosen 'to go outside the system with its obligations and discipline', the pilots could not expect to enjoy the benefits and protection of that system and of the ACTU (Singleton 1990: 189). There was little resistance to the ALP and ACTU agenda from the left unions, and delegates at the 1989 ACTU Congress voted unanimously for a motion that backed the ACTU's position.

Each of these components of the Accord process — the integration of the militant AMWU, wage suppression, and suppression of industrial action-were central to the advance of neoliberalism in Australia. On the basis of this dynamic, the Accord cannot be separated from its neoliberal 'other'. Rather, the stability of the Accord was central to the ALP Government's successful neoliberal restructuring of Australian society.

\section{Theorising the Accord-neoliberalism relationship}

Gramsci's conception of the integral state, alongside interrelated concepts such as hegemony, can assist to critically analyse how state and political society administered Australian capitalism during the vanguard phase of neoliberal restructuring. More particularly, and as detailed above, the integration of the labour movement and trade union leadership through the Accord was a central aspect of vanguard neoliberalism. Political responses to the crises and contradictions afflicting Australian society in the 1970s and early 1980s can thus be perceived as able to come 'from above' and 'from below'. However, the latter responses_-such as those embodied by labourism and its corporatist aspects—were characterised by attempts to integrate subaltern groups into political society (or state) imperatives in a way that could directly undermine subaltern social groups' 
interests. The conception of the integral state, of the separation and dialectical unity of the state and civil society, provides a tool to understand why the Accord became a high point of integration efforts in the neoliberal era.

It is too simple to argue that the Accord assisted the introduction of neoliberal policies through its various effects, although it did have that result in many ways. Distinctively, the agreement orchestrated the consent necessary for the neoliberal project to take hold-including its central elements of wage suppression and quashing of industrial militancy — by integrating the unions and the working class into the efforts of political society to construct a new form of state rule. The Accord and neoliberalism were internally related; and corporatism was the form and method that vanguard neoliberalism took in Australia.

Panitch's analysis of corporatism and Gramsci's heuristic helps to delineate the changing relations between state, political society and civil society in the Accord era. Changes in the political economy were facilitated by the Accord, via the leading role of the state, with a Labor government in power. It was through the Accord process that the neoliberal political project transformed civil society, including the economy, with the labour movement acting as the ultimate tool of macroeconomic policy by voluntarily acceding to an increased rate of exploitation in the form of wage suppression. The Accord also facilitated the enwrapment of civil society by political society and the state, in order to ensure particular policy ends could be achieved.

\section{Conclusion}

The Accord and neoliberalism must be considered as features of a unitary process. In part, this was achieved through the Accord operating on formal and informal levels. It was also achieved as a result of the harmony between central elements of neoliberalism and the Accord. Neoliberalism arose in Australia through, and in concord with, its corporatist 'other', and the Accord was fashioned and reshaped over time to facilitate this structural adjustment. The policy process and economic restructuring under the Hawke-Keating governments were the result of the Accord being coterminal with the implementation of vanguard neoliberalism, in a process of simultaneously deepening corporatism and advancing neoliberalism.

In the case of Australia, the implementation of vanguard neoliberalism occurred through a 'positive' corporatist project centred on working class sacrifice in the national interest. In turn, the use of corporatism within vanguard neoliberalism led to a particular method of labour disorganisation- 
one marked by the labour movement implementing successful wage suppression and self-policing of industrial activity. Amid calls for a new social contract between the union and government-calls that are at times about an alternate project to neoliberalism-being attentive to the internal relationship between the Accord and neoliberalism may alert organised labour to the complex ways in which corporatist arrangements can manifest.

\section{References}

Ahlquist, J.S. (2011) 'Navigating Institutional Change: The Accord, Rogernomics, and the Politics of Adjustment in Australia and New Zealand', Comparative Political Studies 44: 127-55.

Beggs, M. (2015) Inflation and the Making of Australian Macroeconomic Policy, 1945-85. Basingstoke: Palgrave MacMillan.

Bieler, A. (2007) 'Co-option or Resistance? 'Trade Unions and Neoliberal Restructuring in Europe', Capital and Class 93: 111-24.

Birch, K. (2015) 'Neoliberalism: The Whys and Wherefores....and Future Directions', Sociology Compass 9(7): 571-84.

Bramble, T. (2000) “"The Rise of the Modern Labour Technocrat”: Response', Labour History 79: 179-84.

Bramble, T. (2001) Australian Union Strategies Since 1945, Labour and Industry 11(3): 1-25.

Bramble, T. (2008) Trade Unionism in Australia: A History from Flood to Ebb Tide. Melbourne: Cambridge University Press.

Bramble, T. and Kuhn, R. (1999) 'Social Democracy After the Long Boom: Economic Restructuring Under Australian Labor, 1983 to 1996', pp. 20-55 in M. Upchurch (ed.) The State and Globalization: Comparative Studies of Labour and Capital in National Economies, London: Mansell Publishing.

Brian, B. (1999) 'The Mudginberri Abattoir Dispute of 1985', Labour History 76: 107-24.

Cahill, D. (2008) 'Labo(u)r, the Boom and the Prospects for an Alternative to Neo-liberalism', Journal of Australian Political Economy 61: 321-35.

Cahill, D. (2010) 'Business Mobilisation, the New Right and Australian Labor Governments in the 1980s', Labour History 98: 7-24.

Cahill, D. (2013) 'Ideas-Centred Explanations of the Rise of Neoliberalism: A Critique', Australian Journal of Political Science 48(1): 71-84.

Czada, R. (2011) 'Corporativism’, in B. Badie and D. Berg-Schlosser (eds.), International Encyclopedia of Political Science, London: SAGE. 
Emerson, C. (2015) 'Summit Will Build Consensus for Economic Reform', Australian Financial Review, 14 July.

Ericsen, P. (2004) 'From the Plague to Reith: The Legal Antecedents of the Workplace Relations Act. Marxist Interventions'. Available from: http://www.anu.edu.au/polsci/marx/interventions/law.htm (accessed 21 June 2015).

Frankel, B. (1997) 'Beyond Labourism and Socialism: How the Australian Labor Party Developed the Model of "New Labour", , New Left Review 221: 3-33.

Gramsci, A. (1971) Selections from the Prison Notebooks of Antonio Gramsci, London: Lawrence and Wishart.

Griffiths, P. (1989) 'The Social Roots of the Labor Tradition', The Socialist, Sydney, December.

Hampson, I. (1997) 'The End of the Experiment: Corporatism Collapses in Australia', Economic and Industrial Democracy 18: 539-66.

Harvey, D. (2005) A Brief History of Neoliberalism, Oxford: Oxford University Press.

Howes, P. (2014) Speech by Australian Workers' Union, Canberra. Available from: http://www.awu.net.au/opinions/paul-howes-address-national-press-club-5214 (accessed 8 January 2014).

Humphrys, E. (2016) 'The Corporatist Origins of Neoliberalism: Australia's Accord, the Labour Movement and the Neoliberal Project', PhD, Department of Political Economy: University of Sydney.

Jessop, B. (2002) 'Liberalism, Neoliberalism, and Urban Governance: A State-Theoretical Perspective', Antipode 34(3): 452-72.

Kaptein, E. (1993) 'Neo-liberalism and the Dismantling of Corporatism in Australia', pp. 79-109 in H. W. Overbeek (ed.) Restructuring Hegemony in the Global Political Economy: The Rise of Transnational Neoliberalism in the 1980s, London: Routledge.

Krinsky, J. (2011) 'Neoliberal Times: Intersecting Temporalities and the Neoliberalisation of New York City’s Public-Sector Labor Relations', Social Science History 35(3): 381-422.

Lehmbruch, G. (1977) 'Liberal Corporatism and Party Government', Comparative Political Studies 10: 91-126.

McPhillips, J. (1985) The Accord and its Consequences: Trade Union Experiences, Surry Hills: Socialist Party of Australia.

Morton, A.D. (2007) Unravelling Gramsci: Hegemony and Passive Revolution in the Global Political Economy, London: Pluto Press.

Norington, B. (1990) Sky Pirates: The Pilots' Strike that Grounded Australia, Crows Nest: Australian Broadcasting Corporation. 
Panitch, L. (1976) Social Democracy and Industrial Militancy: The Labour Party, the Trade Unions and Incomes Policy, 1945-1974, Cambridge: Cambridge University Press.

Panitch, L. (1980) 'Recent Theorisations of Corporatism: Reflections on a Growth Industry', The British Journal of Sociology 31(2): 159-87.

Panitch, L. (1981) 'Trade Unions and the Capitalist State', New Left Review 1(125): 21-43.

Panitch, L. (1986) 'The Tripartite Experience', pp. 37-119 in K. Banting (ed.) The State and Economic Interests, Toronto: University of Toronto Press.

Peck, J., Theodore, N. and Brenner, N. (2009) 'Postneoliberalism and its Malcontents', Antipode 41(S1): 94-116.

Peetz, D. (2013) 'The Lessons of the Accord for Modern Times: Think Outside the Box', The Conversation, 10 June. Available from: https://theconversation.com/the-lessons-of-theaccord-for-modern-times-think-outside-the-box-14985 (accessed 26 June 2017).

Pusey, M. (1991) Economic Rationalism in Canberra: A Nation Building State Changes its Mind, Cambridge: University of Cambridge.

Rogers, C. (2014) 'From Union Legislation to Financial Reform: A Reflection on Thatcherism, Capital and the British State', Capital and Class 38(2): 289- 302.

Ross, L. (2004) Dare to Struggle, Dare to Win!: Builders Labourers Fight Deregistration 1981-94, Carlton North: Vulgar Press.

Scalmer, S. and Irving, T. (1999) 'The Rise of the Modern Labour Technocrat: Intellectual Labour and the Transformation of the Amalgamated Metal Workers' Union, 1973-85', Labour History 77: 64-82.

Schmitter, P. C. (1979) 'Still the Century of Corporatism?', pp. 7-52, in P. C. Schmitter and G. Lehmbruch (edss), Trends Toward Corporatism Intermediation, London: SAGE Publications.

Singleton, G. (1990) The Accord and the Australian Labour Movement, Carlton: Melbourne University Press.

Spies-Butcher, B. (2012) 'Markets with Equity? Lessons from Australia's Third Way Response to Neoliberalism', pp. 204-27, in D. Cahill, L. Edwards and F. Stilwell (eds.), Neoliberalism: Beyond the Free Market, Cheltenham: Edward Elgar.

Thomas, P. (2009) The Gramscian Moment, Historical Materialism Book Series, Leiden: Brill.

Wilson, F. L. (1983) 'Interest Groups and Politics in Western Europe: The Neo-Corporatist Approach', Comparative Politics 16(1): 105-23. 